\title{
Wpływ leku sakubitril/walsartan na funkcjonalną niedomykalność zastawki mitralnej w HFrEF
}

\section{The impact of sacubitril/valsartan on functional mitral regurgitation in HFrEF}

\author{
Joanna Berner, Małgorzata Lelonek \\ Zakład Kardiologii Nieinwazyjnej Katedry Chorób Wewnętrznych i Kardiologii Uniwersytetu Medycznego w Łodzi
}

\section{Streszczenie}

U pacjenta w wieku 65 lat z przewlekłą niewydolnością serca z obniżoną frakcją wyrzutową lewej komory, będącego w III klasie według New York Heart Association oraz z licznymi chorobami współistniejącymi, w tym ciężką funkcjonalną niedomykalnością zastawki mitralnej (FMR), zgodnie z wytycznymi Europejskiego Towarzystwa Kardiologicznego z 2016 roku w miejsce sartanu włączono sakubitril/walsartan. W dalszej obserwacji wraz z poprawą kliniczną odnotowano istotną redukcję zaawansowania FMR. Na podstawie przypadku klinicznego przedstawiono aktualny stan wiedzy na temat licznych korzyści stosowania sakubitrilu/walsartanu w codziennej praktyce.

Słowa kluczowe: niewydolność serca, sakubitril/walsartan, funkcjonalna niedomykalność mitralna

Folia Cardiologica 2018; 13, 5: 474-480

\section{Wstęp}

Niewydolność serca (HF, heart failure) stanowi poważne wyzwanie dla systemów opieki zdrowotnej [1]. Charakteryzuje się wysoką zapadalnością - w Polsce szacunkowa liczba chorych na HF stanowi między 600 tys. [2] a 700 tys. osób [3]. Mimo postępu w kardiologii HF ma wysoką śmiertelność; 11\% pacjentów umiera w 1. roku po hospitalizacji [4]. Ta jednostka chorobowa pochłania znaczne nakłady finansowe (1,73 mld PLN/rok [5]), które wynikają głównie z częstych rehospitalizacji [6]. Wśród czynników zwiększających ryzyko wystąpienia hospitalizacji z powodu HF jest niedomykalność mitralna [7].

U około 30\% pacjentów z HF stwierdza się umiarkowaną/ciężką niedomykalność zastawki mitralnej (MR, mitral regurgitation). Niezależnie od innych czynników ryzyka MR związana z dysfunkcją skurczową lewej komory - funkcjonalna niedomykalność mitralna (FMR, functional mitral regurgitation) - jest najsilniejszym predyktorem zgonu u pacjentów z HF [8, 9]. Ryzyko zgonu istotnie wzrasta wraz ze stopniem zaawansowania MR w spoczynku, a także przy nasilaniu MR podczas wysiłku [10].

U pacjentów z niewydolnością serca z obniżoną frakcją wyrzutową (HFrEF, heart failure with reduced ejection fraction) dochodzi do niekorzystnego remodelingu lewej komory (LV, left ventricle), który prowadzi do poszerzania pierścienia zastawki mitralnej oraz przebudowy aparatu zastawkowego. Remodeling zastawki mitralnej wynika ze wzrostu stężenia kwasu deoksyrybonukleinowego, glikozaminoglikanu oraz kolagenu [11]. Zmniejszona kurczliwość LV, dyssynchronia skurczu LV, a także zmniejszona kurczliwość pierścienia mitralnego zmniejszają ciśnienie skurczowe LV, co w rezultacie wpływa na ograniczenie siły zamykania płatków zastawki mitralnej, powodując jej funkcjonalną niedomykalność [12].

Udokumentowano również, że nawet łagodna FMR zwiększa ryzyko rozwoju pozawałowej dysfunkcji skurczowej LV [13] oraz na każdym stopniu zaawansowania predysponuje do remodelingu LV i jej rozstrzeni, co skutkuje rozwojem $\mathrm{HF}$ [13]. 
W wytycznych Europejskiego Towarzystwa Kardiologicznego (ESC, European Society of Cardiology), zaktualizowanych w 2016 roku, dotyczących postępowania w niewydolności serca, dużo miejsca poświęcono optymalizacji farmakoterapii HF oraz wprowadzono nową grupę leków - antagonistę receptora dla angiotensyny II i inhibitora neprilizyny (ARNI, angiotensin receptor-nephrilysin inhibitor). Światowy rejestr QUALIFY (Quality of adherence to guideline recommendations for live-saving treatment in heart failure: an international survey) przedstawia stosowanie farmakoterapii w HFrEF w ambulatoryjnej praktyce [14], w tym dane dla polskiej populacji [15]. Większość pacjentów biorących udział w rejestrze była leczona standardowymi grupami leków zgodnie z zaleceniami ESC: inhibitorami konwertazy angiotensyny (ACE, angiotensin-converting enzyme)/antagonistami receptora angiotensyny II (ARB, angiotensin receptor blockers) (92\%), beta-adrenolitykami (97\%) oraz antagonistą receptora dla mineralokortykoidów (MRA, mineralocorticoid receptor antagonist) (73,2\%). Natomiast kluczową kwestią w farmakoterapii pacjenta z HFrEF jest dążenie do docelowych dawek poszczególnych grup leków, w odniesieniu do których udokumentowano poprawę rokowania w HFrEF. Rejestr QUALIFY pokazuje, że jedynie 27,4\% pacjentów było leczonych docelowymi dawkami inhibitorów ACE, 17,7\% - docelowymi dawkami beta-adrenolityków, a 66\% - docelowymi dawkami MRA [15].

Optymalna farmakoterapia ma szczególne znaczenie dla pacjentów z HFrEF i FMR. Wprowadzony do leczenia HFrEF sakubitril/walsartan jest jedynym przedstawicielem grupy ARNI. Jego działanie polega na jednoczasowym blokowaniu receptora dla angiotensyny II (walsartan) oraz inhibicji neprylizyny (sakubitril). Hamowanie neprilizyny wykazuje korzystne działanie na układ sercowo-naczyniowy przez efekt naczyniorozszerzający i zwiększenie dostępności peptydów natriuretycznych, co w rezultacie prowadzi do wzrostu natriurezy i diurezy, a także ograniczenia remodelingu lewej komory.

Na rycinie 1 przedstawiono algorytm postępowania w przewlekłej HFrEF lewej komory uwzględniający nową grupę leków ARNI. Wysoka pozycja leku sakubitril/walsartan w wytycznych ESC 2016 oraz przełomowe wyniki badania PARADIGM-HF (Prospective Comparison of

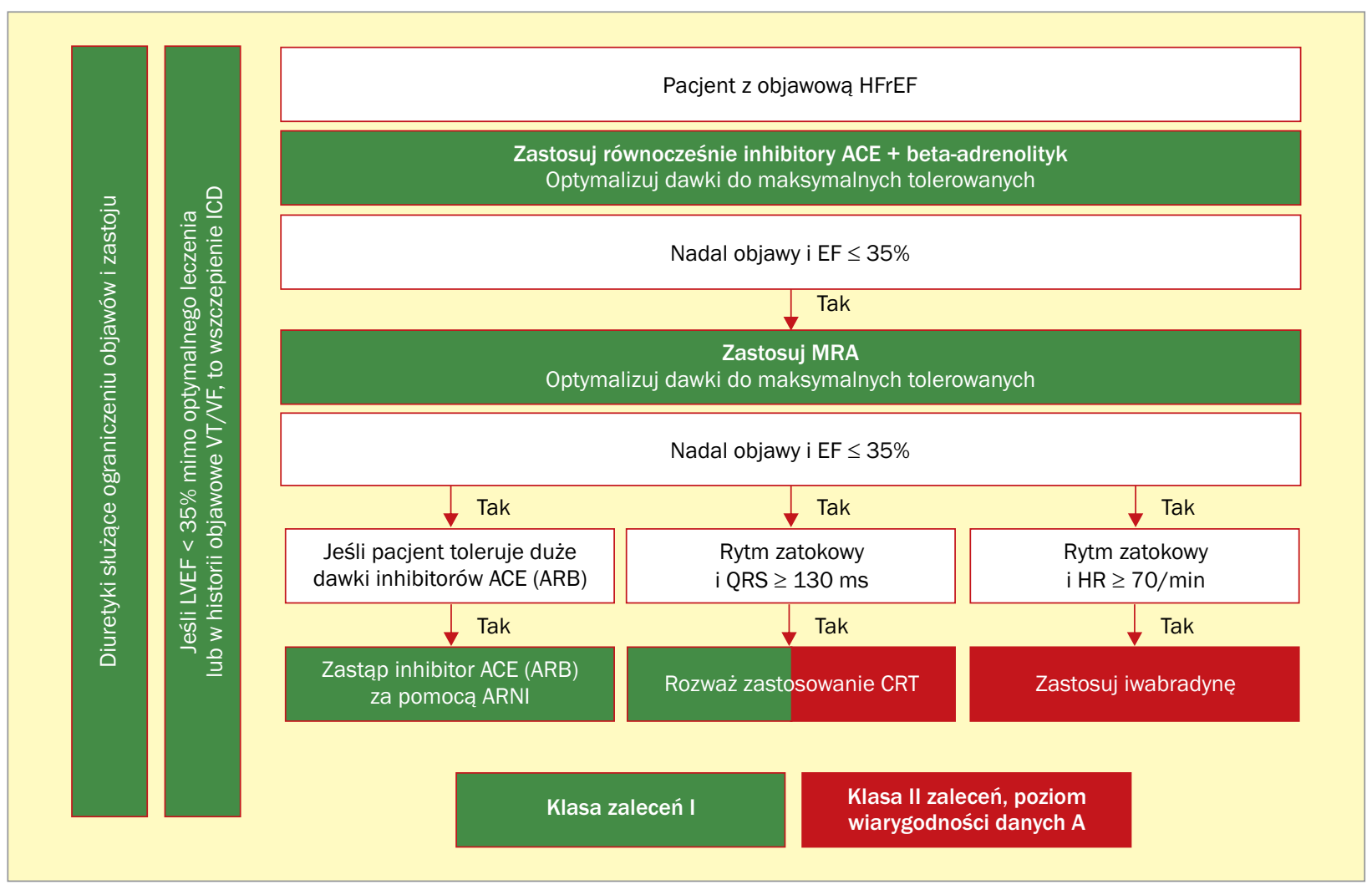

Rycina 1. Algorytm postępowania w niewydolności serca z obniżoną frakcją wyrzutową (HFrEF, heart failure with reduced ejection fraction) (zmodyfikowano na podstawie [1]); LVEF (left ventricular ejection fraction) - frakcja wyrzutowa lewej komory; VT/VF (ventricular tachycardia/ /ventricular fibrillation) - migotanie komór/częstoskurcz komorowy bez tętna; ICD (implantable cardioverter-defibrillator) - implantowalny kardiowerter-defibrylator; ACE (angiotensin-converting enzyme) - inhibitor konwertazy angiotensyny; EF (ejection fraction) - frakcja wyrzutowa; MRA (mineralocorticoid receptor antagonist) - antagonista receptora dla mineralokortykoidów; ARB (angiotensin receptor blockers) - antagonista receptora angiotensyny II; ARNI - angiotensin receptor-nephrilysin inhibitor; HR (heart failure) - niewydolność serca; CRT (cardiac resynchronization therapy) - terapia resynchronizująca 
Tabela 1. Dane z badania PARADIGM-HF (Prospective Comparison of ARNI with ACEI to Determine Impact on Global Mortality and Morbidity in Heart Failure) (na podstawie [16])

\begin{tabular}{ll}
\hline Parametr & Wartość \\
\hline Liczba pacjentów & 8442 \\
Charakterystyka populacji & LVEF < 40\% \\
& II-IV klasa wg NYHA \\
Leczenie & $97 / 103 \mathrm{mg}$ sakubitril/walsartan $2 \times /$ d. v. $10 \mathrm{mg}$ enalapril 2 ×/d. \\
Pierwszorzędowy punkt końcowy & Zgon z przyczyn sercowo-naczyniowych lub hospitalizacja z powodu zaostrzenia objawów HF \\
Drugorzędowe punkty końcowe & Czas do zgonu z jakiejkolwiek przyczyny \\
& Poprawa jakości życia \\
& Czas do pierwszego napadu migotania przedsionków \\
& Czas do pierwszorazowego pogorszenia funkcji nerek \\
& Obniżenie ryzyka wystąpienia pierwszorzędowego punktu końcowego o 20\% \\
Wyniki & Obniżenie ryzyka zgonu z jakiejkolwiek przyczyny o 16\% \\
& Poprawa jakości życia dzięki leczeniu sakubitrilem/walsartanem \\
& Brak istotnej statystycznie różnicy w pozostałych punktach końcowych \\
LVEF (left ventricular ejection fraction) - frakcja wyrzutowa lewej komory; NYHA - New York Heart Association; cvD (cardiovascular diseases) - choroby układu sercowo-naczyniowego; HF (heart failure) - \\
niewydolnośc serca
\end{tabular}

Tabela 2. Profil kliniczny pacjenta biorącego udział w badaniu PARADIGM-HF (Prospective Comparison of ARNI with ACEI to Determine Impact on Global Mortality and Morbidity in Heart Failure) (na podstawie [16]) oraz przedstawianego pacjenta

$\begin{array}{lcc}\text { Parametr } & \begin{array}{c}\text { Populacja } \\ \text { PARADIGM-HF }\end{array} & \text { Pacjent } \\ \text { Wiek (lata) } & 63,8 \pm 11,5 & 65 \\ \text { Ciśnienie tętnicze [mm Hg] } & 122 \pm 15 / & 125 / 90 \\ & / 72 \pm 12 & \\ \text { Klasa wg NYHA } & \text { II (71,6\%) } & \text { III } \\ & \text { III }(23,1 \%) & \\ \text { EF (\%) } & 29,6 \pm 6,1 & 31 \\ \text { BNP mediana [pg/ml] } & 255(155-474) & - \\ \text { NT-proBNP mediana [pg/ml] } & 1631 & 3342 \\ & (885-3154) & \\ \text { Kreatynina [mg/dl] } & 1,13 \pm 0,3 & 1,4\end{array}$

NYHA - New York Heart Association; EF (ejection fraction) - frakcja wyrzutowa; BNP (B-type natriuretic peptide) - peptyd natriuretyczny typu B; NT-proBNP (N-terminal pro-B-type natriuretic peptide) - N-końcowy fragment propeptydu natriuretycznego typu B

ARNI with ACEI to Determine Impact on Global Mortality and Morbidity in Heart Failure) (tab. 1) [16], w którym udowodniono wyższą skuteczność ARNI w porównaniu $z$ enalaprilem w zapobieganiu śmiertelności z przyczyn sercowo-naczyniowych, jak i śmiertelności całkowitej, a także rehospitalizacjom z powodu zaostrzenia HF, skłaniają do włączania tej grupy leków u coraz większej populacji pacjentów z HFrEF. W tabeli 2 przedstawiono profil kliniczny pacjenta z badania PARADIGM-HF, będący wskazówką przy włączaniu leku z grupy ARNI.

Dotąd nie ma doniesień o możliwym korzystnym wpływie leku sakubitril/walsartan na FMR, choć biorąc pod uwagę mechanizm działania leku, wydaje się, że sakubitril/ /walsartan może prowadzić do redukcji FMR. W niniejszym artykule przedstawiono przypadek pacjenta z przewlekłą HFrEF, u którego uzyskano istotną redukcję FMR podczas terapii lekiem sakubitril/walsartan.

\section{Opis przypadku}

Pacjent w wieku 65 lat z pozawałową dysfunkcją skurczową lewej komory w III klasie według New York Heart Association (NYHA), ze współistniejącą istotną FMR, pozostający pod stałą opieką ambulatoryjną w warunkach poradni kardiologicznej.

Pacjent ma rozpoznaną przewlekłą chorobę wieńcową z wieloma incydentami wieńcowymi. Przebył pomostowanie aortalno-wieńcowe 5 września 2016 roku (zespolenie tętnicy piersiowej wewnętrznej lewej z gałęzią międzykomorową przednią lewej tętnicy wieńcowej [LIMA-LAD, left mammary artery grafts to left anterior descending artery] - by-pass tętniczy do lewej tętnicy wieńcowej; by-pass żylny do gałęzi marginalnej oraz do prawej tętnicy wieńcowej [SBG-Mg i RCA]), z okołozabiegowym zawałem serca ściany dolnej. Pacjent przebył zawał serca ściany dolnej i przedniej powikłany wstrząsem kardiogennym w październiku 2010 roku, przeprowadzono u niego angioplastykę wieńcową w zakresie RCA i gałęzi okalającej (Cx, circumflex artery) w 2010 roku. Jest po angioplastyce wieńcowej pomostu LIMA-LAD z implantacją stentu uwalniającego lek (DES, drug-eluting stents) w grudniu 2016 roku. Dodatkowo jest obciążony nadciśnieniem tętniczym dobrze kontrolowanym farmakologicznie, cukrzycą typu 2 leczoną preparatami doustnymi oraz dyslipidemią w trakcie terapii statyną.

Pacjent był hospitalizowany z powodu zaostrzenia HFrEF od 11 do 19 grudnia 2016 roku. W trakcie hospitalizacji wykonano badanie echokardiograficzne, w którym 
Tabela 3. Stosowana farmakoterapia

$\begin{array}{lcccc}\text { Lek } & \text { 1. wizyta } & \text { 2. wizyta } & \text { 3. wizyta } & \text { 4. wizyta } \\ \text { Sakubitril/walsartan } & - & 2 \times 49 / 51 \mathrm{mg} & \mathbf{2} \times 97 / 103 \mathrm{mg} & \mathbf{2} \times 97 / 103 \mathrm{mg} \\ \text { Kwas acetylosalicylowy } & 75 \mathrm{mg} & 75 \mathrm{mg} & 75 \mathrm{mg} & 75 \mathrm{mg} \\ \text { Klopidogrel } & 75 \mathrm{mg} & 75 \mathrm{mg} & 75 \mathrm{mg} & 75 \mathrm{mg} \\ \text { Bisoprolol } & 2,5 \mathrm{mg} & 3,75 \mathrm{mg} & 3,75 \mathrm{mg} & 3,75 \mathrm{mg} \\ \text { Walsartan } & 2 \times 160 \mathrm{mg} & - & - & - \\ \text { Torasemid } & 5 \mathrm{mg} & 10 \mathrm{mg} & 10 \mathrm{mg} & \mathbf{5 m g} \\ \text { Eplerenon } & 25 \mathrm{mg} & 25 \mathrm{mg} & 12,5 \mathrm{mg} & 12,5 \mathrm{mg} \\ \text { Furosemid } & 40 \mathrm{mg} & 40 \mathrm{mg} & 40 \mathrm{mg} & - \\ \text { Rosuwastatyna } & 20 \mathrm{mg} & 20 \mathrm{mg} & 20 \mathrm{mg} & 20 \mathrm{mg} \\ \text { Metformina } & 3 \times 500 \mathrm{mg} & 3 \times 500 \mathrm{mg} & 3 \times 500 \mathrm{mg} & 3 \times 500 \mathrm{mg} \\ \text { Pantoprazol } & 20 \mathrm{mg} & 20 \mathrm{mg} & 20 \mathrm{mg} & 20 \mathrm{mg}\end{array}$

zobrazowano ciężką pozawałową dysfunkcję LV z frakcją wyrzutową (EF, ejection fraction) 31\%, z rozległymi odcinkowymi zaburzeniami kurczliwości ścian LV: akinezą segmentów koniuszkowych części ściany bocznej oraz tylnej, hipokinezą pozostałych segmentów. Dodatkowo stwierdzono ciężką dysfunkcję skurczową prawej komory (pomiar wychylenia skurczowego pierścienia trójdzielnego [TAPSE, tricuspid annular plane systolic excursion] $8 \mathrm{~mm}$ ) z jej rozstrzenią, z towarzyszącą ciężką funkcjonalną niedomykalnością zastawki trójdzielnej. Niedomykalność zastawki mitralnej także oceniono jako ciężką. Podczas standardowego leczenia HF uzyskano poprawę i stabilizację kliniczną. W wykonanym teście sześciominutowego marszu pacjent pokonał dystans 220 metrów z nasileniem duszności 0-5 w skali Borga.

Podczas wizyty kontrolnej w poradni kardiologicznej w styczniu (1. wizyta) pacjent pozostawał w III klasie według NYHA. W badaniu przedmiotowym stwierdzono osłuchowo pojedyncze trzeszczenia u podstawy obu płuc, tętnienie poszerzonych żył szyjnych, dodatni objaw wątrobowo-szyjny. Ciśnienie tętnicze (BP, blood pressure) wynosiło 125/90 mm Hg, stężenie N-końcowego fragmentu propeptydu natriuretycznego typu B (NT-proBNP, $\mathrm{N}$-terminal pro-B-type natriuretic peptide) $3342 \mathrm{pg} / \mathrm{ml}$. Frakcja wyrzutowa lewej komory pogorszyła się i wynosiła 23\%. Zmodyfikowano leczenie. W tabeli 3 przedstawiono stosowaną u pacjenta farmakoterapię, zgodną z zaleceniami ESC w maksymalnych tolerowanych przez chorego dawkach poszczególnych leków. Pacjent był konsultowany kardiochirurgicznie i wstępnie zaproponowano kwalifikację do przeszczepu serca lub leczenia przezskórnego metodą MitraClip FMR po wykonaniu dalszych badań echokardiograficznych oraz inwazyjnych.

Podczas ponownej wizyty ambulatoryjnej u kardiologa w lutym (2. wizyta) zmodyfikowano stosowaną farmakoterapię - zwiększono dawkowanie beta-adrenolityku oraz zgodnie z najnowszymi wytycznymi leczenia HF, sartan zastąpiono ARNI - sakubitrilem/walsartanem w dawce początkowej 49/51 mg 2 razy/dobe - przy BP 125/80 mm Hg.

Po miesiącu (3. wizyta) stosowania leku sakubitril/ /walsartan ciśnienie tętnicze wynosiło 120/78 mm Hg. U pacjenta stwierdzono poprawę klasy czynnościowej do II klasy według NYHA oraz znaczną redukcję objawów przedmiotowych niewydolności serca: nie stwierdzono tętnienia ani poszerzenia żył szyjnych, nie obserwowano dodatniego objawu wątrobowo-szyjnego. W kontrolnych badaniach laboratoryjnych udokumentowano prawidłową funkcję nerek (stężenie kreatyniny 1,2 mg/dl, współczynnik filtracji kłębuszkowej [GFR, glomerular filtration rate] $83 \mathrm{ml} / \mathrm{min} / 1,73 \mathrm{~m}^{2}$ ). Ze względu na stężenie potasu powyżej 5,2 mmol/l zmniejszono dawkę eplerenonu (tab. 3). Zgodnie z zaleceniami wytycznych ESC oraz charakterystyką produktu leczniczego zwiększono dawkowanie leku sakubitril/walsartan do dawki docelowej 97/103 mg 2 razy/dobę.

W kwietniu (4. wizyta) w badaniu echokardiograficznym (tab. 4) stwierdzono poprawę funkcji skurczowej lewej i prawej komory z redukcją stopnia zaawansowania FMR z ciężkiej na umiarkowaną. Funkcja skurczowa prawej komory również się poprawiła. Ze względu na brak objawów przewodnienia zredukowano leczenie moczopędne i utrzymano sakubitril/walsartan w dawce docelowej 2 razy 97/103 mg. Chory nie zgłaszał ograniczenia tolerancji wysiłku. Stężenie NT-proBNP wynosiło $611 \mathrm{pg} / \mathrm{ml}$, co korespondowało $z$ istotną poprawą kliniczną. Pacjent powrócił do pracy zawodowej.

Pacjenta ponownie konsultowano kardiochirurgicznie po 3 miesiącach stosowania leku sakubitril/walsartan. W ośrodku kardiologicznym wykonano próbę wysiłkową, która przy obciążeniu 4,9 równoważnika metabolicznego (MET, metabolic equivalent) była ujemna klinicznie 
Tabela 4. Wyniki badań echokardiograficznych

\begin{tabular}{|c|c|c|}
\hline Parametr & 1. TTE & TTE po 3 mies. \\
\hline $\mathrm{EF}(\%)$ & 23 & 35 \\
\hline LVDD/LVSD [mm] & $65 / 56$ & $61 / 55$ \\
\hline LVEDV/ESV [ml] & $193 / 149$ & $176 / 114$ \\
\hline $\mathrm{LAV}[\mathrm{ml}]$ & 79 & 68 \\
\hline TAPSE [mm] & 10 & 16 \\
\hline PASP [mm Hg] & 40 & 35 \\
\hline $\mathrm{ERO}\left[\mathrm{cm}^{2}\right]$ & 0,2 & 0,12 \\
\hline $\mathrm{PISA}[\mathrm{mm}]$ & 7 & 3 \\
\hline \multicolumn{3}{|c|}{ 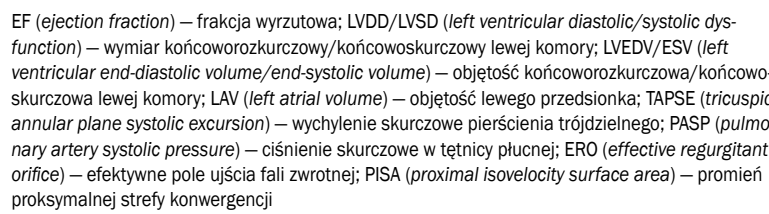 } \\
\hline
\end{tabular}

i elektrokardiograficznie, oraz koronarografię, w której nie stwierdzono progresji choroby wieńcowej. Uwidoczniono prawidłowo funkcjonujące by-passy aortalno-wieńcowe. Ze względu na całość obrazu klinicznego oraz znaczną poprawę stanu ogólnego pacjenta odstąpiono od kwalifikacji do leczenia zabiegowego. W zakresie farmakoterapii pozostawiono docelową dawkę ARNI oraz zmniejszoną dawkę diuretyku (tab. 3).

Po 9 miesiącach terapii lekiem sakubitril/walsartan chory jest stabilnym stanie, bez ograniczenia tolerancji wysiłku, pracuje, stężenie NT-proBNP wyniosło 411 pg/ml. Ze względu na brak objawów HF oraz poprawę EF odroczono konsultację elektrofizjologiczną. Kolejną ocenę kliniczą i echokradiograficzną zaplanowano za 3 miesiące.

\section{Omówienie}

Przedstawiony przypadek kliniczny ukazuje skuteczność optymalnej terapii zaawansowanej HFrEF z towarzyszącą FMR z zastosowaniem leku sakubitril/walsartan. W literaturze brakuje doniesień na temat wpływu leczenia ARNI na FMR.

Współwystępowanie FMR oraz HF pogarsza rokowanie pacjenta bez względu na etiologię FMR - niedokrwienną czy nieniedokrwienną [17]. Funkcjonalna niedomykalność zastawki mitralnej nie jest pierwotnie chorobą zastawkową, lecz konsekwencją restrykcji płatków zastawki z poszerzeniem jej pierścienia będącej wynikiem dysfunkcji LV, remodelingu i zmniejszonej siły zamykającej płatki [18]. Wyższy stopień zaawansowania FMR wiąże się z gorszym rokowaniem pacjenta. Leczenie powinno opierać się na optymalnej farmakoterapii oraz na ustaleniu wskazań do leczenia inwazyjnego. Obecnie dostępne są dwie możliwości zabiegowego leczenia FMR - klasyczna operacja kardiochirurgiczna lub przezskórne metody, takie jak
MitraClip, polegające na zmniejszaniu stopnia niedomykalności przez łączenie ze sobą brzegów płatków [19].

Pacjenci z istotną FMR poddawani pomostowaniu aortalno-wieńcowemu (CABG, coronary artery bypass grafting) powinni mieć jednoczasowo wykonywaną korekcję chirurgiczną zastawki mitralnej (klasa zaleceń I, poziom wiarygodności danych C). Zabieg operacyjny należy rozważyć u objawowych chorych z EF poniżej 30\% i warunkami do rewaskularyzacji oraz żywotnym mięśniem sercowym (Ilb C). Natomiast zabieg można rozważyć w przypadku ciężkiej MR z EF powyżej 30\%, gdy pacjent ma objawy HF mimo optymalnego leczenia uwzględniającego terapię resynchronizująca (CRT, cardiac resynchronization therapy) oraz niskie ryzyko operacji (IIb C) [18]. Jeśli rewaskularyzacja nie jest planowana, a ryzyko chirurgiczne nie jest niskie, to można rozważyć przezskórną metodę edge-to-edge (Mitraclip) u objawowych chorych z ciężką MR, jeśli są spełnione warunki echokardiograficzne w zakresie zastawki (klasa IIb, C) [18].

Korzystny wielokierunkowy efekt działania leku sakubitril/walsartan, przez blokowanie receptora angiotensyny II (rozszerza naczynia, hamuje układ współczulny, zmniejsza retencję sodu i wody, powodując działanie odwadniające, hamuje procesy włóknienia i przerostu) oraz hamowanie neprilizyny (nasila korzystne działanie peptydów natriuretycznych: naczyniorozszerzające, zwiększające natriurezę i diurezę, a także hamujące procesy włóknienia i przerostu), powoduje zmniejszenie oporu naczyniowego, redukcję obciążenia następczego lewej komory oraz ogranicza remodeling LV przez hamowanie procesów włóknienia [20]. Procesy te, korzystnie wpływając na ograniczenie remodelingu lewej komory, mogą hamować postęp FMR lub całkowicie ją ograniczyć.

W badaniu in vitro von Lueder i wsp. [21] udowodnili korzystny wpływ leku sakubitril/walsartan na pozawałowy remodeling lewej komory. Udokumentowano zmniejszenie późnorozkurczowej objętości LV oraz poprawę funkcji skurczowej LV. Połączenie działania inhibitora receptora angiotensyny II i neprilizyny potęguje korzystne działanie walsartanu w zakresie hamowania procesów włóknienia i remodelingu LV [22]. Wpływ leku sakubitril/walsartan na FMR wymaga jednak dalszych badań i obserwacji.

Zgodnie z wynikami badania PARADIGM-HF największą korzyść z leczenia lekiem sakubitril/walsartan odniosą pacjenci z HF spełniający następujące kryteria [16]:

- stabilna przewlekła HF;

- EF nie wyższa niż 40\%;

- optymalne standardowe leczenie HF zgodne z wytycznymi ESC;

- wcześniejsza hospitalizacja z powodu HF w ostatnich 12 miesiącach istężenie NT-proBNP co najmniej 400 pg/ml (w przypadku braku hospitalizacji z powodu HF w ostatnich 12 miesiącach - NT-proBNP $\geq 600$ pg/ml); 
- tolerancja dawki leku enalapril 2 razy $10 \mathrm{mg} /$ dobę lub dawki ekwiwalentnej.

Leku sakubitril/walsartan nie należy stosować u pacjentów z wyjściowym stężeniem potasu w surowicy powyżej 5,4 mmol/l lub ze skurczowym ciśnieniem tętniczym poniżej $100 \mathrm{~mm} \mathrm{Hg}$ [23].

Sakubitril/walsartan jest dostępny w 3 dawkach: 24/26 mg, 49/51 mg oraz 97/103 mg. Biodostępność walsartanu w połączeniu z sakubitrilem jest wyższa niż walsartanu w monoterapii, dlatego też dawki 26, 51 i 103 mg odpowiadają, odpowiednio: 40, 80 i 160 mg walsartanu [24].

Zastosowanie mniejszej dawki początkowej sakubitrilu/ /walsartanu $24 \mathrm{mg} / 26 \mathrm{mg} 2$ razy/dobę należy rozważyć u pacjentów z SBP co najmniej 100-110 mm Hg oraz u pacjentów z umiarkowanymi zaburzeniami czynności nerek, z wyliczonym wskaźnikiem przesączania kłębuszkowego (eGFR, estimated GFR) na poziomie 30-60 ml/ $/ \mathrm{min} / 1,73 \mathrm{~m}^{2}$ [23].

Zaleca się dążenie do dawki docelowej leku sakubitril/ /walsartan na poziomie $97 \mathrm{mg} / 103$ mg podawanej 2 razy/ /dobę przez stopniowe zwiększanie dawkowania leku pod kontrolą BP, GFR i stężenia potasu w surowicy. Optymalnie dawkę docelową leku powinno się osiągnąć w ciągu 3-6 tygodni leczenia [25, 26].

W prezentowanym przypadku klinicznym pacjent, ze względu na prawidłową funkcję nerek oraz wartość SBP powyżej $110 \mathrm{~mm} \mathrm{Hg}$, rozpoczął terapię lekiem sakubitril/ /walsartan od dawki 49/51 mg stosowanej 2 razy/dobę. Po kontroli parametrów nerkowych i ciśnienia tętniczego zgodnie z zaleceniami zwiększono dawkę do dawki docelowej - 97/103 mm Hg. Zwiększanie dawek leku należy rozważać nie częściej niż co 2 tygodnie.

Dzięki zastosowanemu leczeniu ARNI pacjent odniósł korzyści kliniczne: poprawe jakości życia z ustąpieniem duszności wysiłkowej, znaczą redukcję wartości NT-pro-BNP (z 3342 do 411 pg/ml) oraz poprawę parametrów echokardiograficznych, w tym zmniejszenie stopnia FMR oraz poprawę funkcji skurczowej prawej komory i LV. Umożliwiło to powrót do aktywności zawodowej oraz odstąpienie od proponowanego leczenia kardiochirurgicznego.

$\mathrm{Na}$ świecie aktualnie prowadzone są dalsze badania nad lekiem - ich celem jest rozszerzenie wskazań do jego stosowania, między innymi w niewydolności serca z zachowaną funkcją skurczową LV (badanie PARAGON-HF [Prospective Comparison of ARNI with ARB Global Outcomes in HF With Preserved Ejection Fraction]), u pacjentów hospitalizowanych z powodu zaostrzenia objawów HFrEF (badanie TRANSITION [Comparison of Pre- and Post-discharge Initiation of LCZ696 Therapy in HFrEF Patients After an Acute Decompensation Event]), u dzieci czy w innych populacjach, na przykład w Japonii, jak również w populacji z FMR (badanie PRIME [Pharmacological Reduction of Functional, Ischemic Mitral REgurgitation]). Celem badania PRIME jest sprawdzenie tezy o wyższości sakubitrilu/ /walsartanu nad antagonistą aldosteronu w ograniczaniu postępu FMR u pacjentów z HFrEF [27].

\section{Podsumowanie}

Sakubitril/walsartan okazał się bez wątpienia przełomowy w leczeniu HFrEF [28]. Na podstawie przedstawionego przypadku klinicznego można wnioskować, że wskazania do włączania terapii lekiem będą się rozszerzać. Zastosowanie leku u chorych z HFrEF i towarzyszącą funkcjonalną MR wydaje się pozytywnie wpływać na zmniejszenie jej stopnia zaawansowania. Jednak założenie to wymaga dalszych badań.

\section{Konflikt interesów}

Udział w badaniu TRANSITION (J.B. i M.L.) oraz w badaniu PARAGON-HF (M.L.).

\section{Abstract}

In the drug therapy of a 65-year-old male with chronic heart failure with reduced ejection fraction, New York Heart Association class III, with numerous co-morbidities including severe functional mitral regurgitation (FMR), in accordance with the 2016 European Society of Cardiology guidelines, angiotensin receptor blocker was replaced with sacubitril/ /valsartan. During further ambulatory observation, significantly reduced FMR was noted. This case report presents the current state of knowledge regarding the broad benefits of using sacubitril/valsartan in everyday clinical practice.

Key words: heart failure with reduced ejection fraction, sacubitril/valsartan, functional mitral regurgitation

Folia Cardiologica 2018; 13, 5: 474-480 


\section{Piśmiennictwo}

1. Ponikowski P, Voors AA, Anker SD, et al. ESC Scientific Document Group. 2016 ESC Guidelines for the diagnosis and treatment of acute and chronic heart failure: The Task Force for the diagnosis and treatment of acute and chronic heart failure of the European Society of Cardiology (ESC) developed with the special contribution of the Heart Failure Association (HFA) of the ESC. Eur Heart J. 2016; 37(27): 2129-2200, doi: 10.1093/ /eurheartj/ehw128, indexed in Pubmed: 27206819.

2. Rywik TM, Kołodziej P, Targoński R, et al. Characteristics of the heart failure population in Poland: ZOPAN, a multicentre national programme. Kardiol Pol. 2011; 69(1): 24-31, indexed in Pubmed: 21267960.

3. Rywik TM, Zieliński T, Piotrowski W, et al. Heart failure patients from hospital settings in Poland: population characteristics and treatment patterns, a multicenter retrospective study. Cardiol J. 2008; 15(2): 169-180, indexed in Pubmed: 18651402.

4. Balsam P, Tymińska A, Kapłon-Cieślicka A, et al. Predictors of one-year outcome in patients hospitalized for heart failure: results from the Polish part of the Heart Failure Pilot Survey of the European Society of Cardiology. Kardiol Pol. 2016; 74(1): 9-17, doi: 10.5603/KP.a2015.0112.

5. Czech M, Opolski G, Zdrojewski T, et al. The costs of heart failure in Poland from the public payer's perspective. Polish programme assessing diagnostic procedures, treatment and costs in patients with heart failure in randomly selected outpatient clinics and hospitals at different levels of care: POLKARD. Kardiol Pol. 2013; 71(3): 224-232, doi: 10.5603/KP.2013.0032, indexed in Pubmed: 23575775.

6. Niewydolność serca w Polsce - raport 2016. Materiały informacyjne Sekcji Niewydolności Serca Polskiego Towarzystwa Kardiologicznego (PTK) Warszawa, 2016.

7. Kajimoto K, Sato N, Takano T, et al. Investigators of the Acute Decompensated Heart Failure Syndromes (ATTEND) registry. Functional mitral regurgitation at discharge and outcomes in patients hospitalized for acute decompensated heart failure with a preserved or reduced ejection fraction. Eur J Heart Fail. 2016; 18(8): 1051-1059, doi: 10.1002/ejhf.562, indexed in Pubmed: 27212582.

8. Cioffi G, Tarantini L, De Feo S, et al. Functional mitral regurgitation predicts 1-year mortality in elderly patients with systolic chronic heart failure. Eur J Heart Fail. 2005; 7(7): 1112-1117, doi: 10.1016/j. ejheart.2005.01.016, indexed in Pubmed: 15919238.

9. Bursi F, Enriquez-Sarano M, Nkomo VT, et al. Heart failure and death after myocardial infarction in the community: the emerging role of mitral regurgitation. Circulation. 2005; 111(3): 295-301, doi: 10.1161/01. CIR.0000151097.30779.04, indexed in Pubmed: 15655133.

10. Lancellotti P, Gérard PL, Piérard LA. Long-term outcome of patients with heart failure and dynamic functional mitral regurgitation. Eur Heart J. 2005; 26(15): 1528-1532, doi: 10.1093/eurheartj/ehi189, indexed in Pubmed: 15814566.

11. Grande-Allen KJ, Borowski AG, Troughton RW, et al. Apparently normal mitral valves in patients with heart failure demonstrate biochemical and structural derangements: an extracellular matrix and echocardiographic study. J Am Coll Cardiol. 2005; 45(1): 54-61, doi: 10.1016/j. jacc.2004.06.079, indexed in Pubmed: 15629373.

12. Ennezat $P$, Maréchaux $S$, Pibarot $P$, et al. Secondary mitral regurgitation in heart failure with reduced or preserved left ventricular ejection fraction. Cardiology. 2013; 125(2): 110-117, doi: 10.1159/000350356.

13. Aronson D, Goldsher N, Zukermann R, et al. Ischemic mitral regurgitation and risk of heart failure after myocardial infarction. Arch Intern Med. 2006; 166(21): 2362-2368, doi: 10.1001/archinte.166.21.2362, indexed in Pubmed: 17130390.

14. Komajda M, Anker SD, Cowie MR, et al. QUALIFY Investigators. Physicians' adherence to guideline-recommended medications in heart failure with reduced ejection fraction: data from the QUALIFY global survey. Eur J Heart Fail. 2016; 18(5): 514-522, doi: 10.1002/ /ejhf.510, indexed in Pubmed: 27095461.

15. Opolski G, Ozierański K, Lelonek M, et al. The Polish Qualify Investigators. Adherence to the guidelines on the management of systolic heart failure in ambulatory care in Poland. Data from the international QUALIFY survey. Pol Arch Intern Med. 2017; 127(10): 657-665, doi: 10.20452/pamw.4083, indexed in Pubmed: 28786405.

16. Packer M, McMurray JJV, Desai AS, et al. PARADIGM-HF Investigators and Coordinators, PARADIGM-HF Investigators and Committees. Angiotensin-neprilysin inhibition versus enalapril in heart failure. N Engl J Med. 2014; 371(11): 993-1004, doi: 10.1056/NEJMoa1409077, indexed in Pubmed: 25176015.

17. Benjamin MM, Smith RL, Grayburn PA. Ischemic and functional mitral regurgitation in heart failure: natural history and treatment. Curr Cardiol Rep. 2014; 16(8): 517, doi: 10.1007/s11886-014-0517-0, indexed in Pubmed: 24957516.

18. Baumgartner H, Falk V, Bax JJ, et al. ESC Scientific Document Group. 2017 ESC/EACTS Guidelines for the management of valvular heart disease. Eur Heart J. 2017; 38(36): 2739-2791, doi: 10.1093/eurheartj/ehx391, indexed in Pubmed: 28886619.

19. Feldman T, Foster E, Glower D, et al. Percutaneous repair or surgery for mitral regurgitation. N Engl J Med. 2011; 364(15): 1395-1406, doi: 10.1056/nejmoa1009355.

20. Kaplinsky E. Changing the treatment of heart failure with reduced ejection fraction: clinical use of sacubitril-valsartan combination. J Geriatr Cardiol. 2016; 13(11): 914-923, doi: 10.11909/j.issn.16715411.2016.11.006, indexed in Pubmed: 28133468.

21. von Lueder TG, Wang BH, Kompa AR, et al. Angiotensin receptor neprilysin inhibitor LCZ696 attenuates cardiac remodeling and dysfunction after myocardial infarction by reducing cardiac fibrosis and hypertrophy. Circ Heart Fail. 2015; 8(1): 71-78, doi: 10.1161/CIRCHEARTFAILURE.114.001785, indexed in Pubmed: 25362207.

22. Iborra-Egea 0 , Gálvez-Montón C, Roura S, et al. Mechanisms of action of sacubitril/valsartan on cardiac remodeling: a systems biology approach. NPJ Syst Biol Appl. 2017; 3: 12, doi: 10.1038/s41540-0170013-4, indexed in Pubmed: 28649439.

23. Gu J, Noe A, Chandra P, et al. Pharmacokinetics and pharmacodynamics of LCZ696, a novel dual-acting angiotensin receptor-neprilysin inhibitor (ARNi). J Clin Pharmacol. 2010; 50(4): 401-414, doi: 10.1177/0091270009343932, indexed in Pubmed: 19934029.

24. Entresto ${ }^{\circledast}$-Charakterystyka produktu leczniczego. https://ec.europa.eu/ /health/documents/community-register/2017/20170111136859/ /anx_136859_pl.pdf (18.10.2018).

25. Senni M, McMurray JJV, Wachter R, et al. Initiating sacubitril/valsar$\tan$ (LCZ696) in heart failure: results of TITRATION, a double-blind, randomized comparison of two uptitration regimens. Eur J Heart Fail. 2016; 18(9): 1193-1202, doi: 10.1002/ejhf.548, indexed in Pubmed: 27170530.

26. Chuda A, Lelonek M. Kandydat do nowej terapii niewydolności serca z obniżoną frakcją wyrzutową - ARNI (angiotensin receptor-nephrilysin inhibitor). Przewodnik klinicysty. Folia Cardiol. 2017; 12(4): 397-404, doi: 10.5603/fc.a2017.0048.

27. Pharmacological Reduction of Functional, Ischemic Mitral Regurgitation (PRIME). https://clinicaltrials.gov/ct2/show/NCT02687932 (18.10.2018).

28. Lelonek $M$. The need to apply the best therapy in heart failure - the era after PARADIGM-HF. Arch Med Sci. 2017; 13(5): 1244-1248, doi: 10.5114/aoms.2016.59711, indexed in Pubmed: 28883868. 